\title{
Asafo Music in Context of Simpa Aboakyer Festival
}

\author{
George Asabre Maclean \\ Department of Music Education, University of Education, Winneba \\ * E-mail of the corresponding author: mgeorgeasabre@gmail.com
}

\begin{abstract}
The study investigated how Asafo music accompanies the Aboakyer festival celebrated by the Effutu of Winneba. It took a perfunctory look into the history of the people, the reasons for the celebration of the festival as well as a detailed study of the nature of music performed during the festival celebration. The research design used was ethnographic while interview and participant observation were used to collect the data. Audio recordings were done while musical sounds were transcribed and scored using Finale 2012 music software. It became clear that asafo music is inseparable from the Aboakyer festival as it permeates the entire activities of the festival. Asafo music performance during the festival is not restricted to any particular set of individuals but becomes a public performance where anyone who wishes to perform with an Asafo company could do so. Undoubtedly, Asafo music elements are rich and are source materials for music creative activities.
\end{abstract}

Key words: Aboakyer, Asafo songs, festival, Effutu, Winneba

DOI: $10.7176 /$ RHSS/10-14-09

Publication date:July $31^{\text {st }} 2020$

\section{Introduction}

In Ghana, different festivals are celebrated by the different tribal or ethnic groups at different times of the year for similar and different reasons. These festivals include Odwira among the Twi-speaking Akan, Ohum by the Guan, Ahobaa among the Fante, Homsws by the Ga, Mayem by the Krobo, Hogbetsotso among the Ewe, Damba by the Mole-Dagbani people of Northern Ghana, Kundum by the Nzema, Bakatue by the people of Elmina, Akwambs by the Agona, Ajumako and Gomoa towns, and the Fetu Afahyc by the people of Oguaa (Fynn \& Addo-Fening, 1991). Although there are many festivals celebrated in Ghana among the various ethnic groups, one of such festivals that scholars have given exposure to its popularity is the Aboakyer (deer-hunt) of the Effutu people of Ghana (Adjepong \& Obeng, 2018; Ghunney, 2015; Impraim-Swanzy, 2015; Takyi, 2015; Brown, 2005 \& Wyllie, 1994). Etymologically, Aboakyer comprises two words - 'aboa' which means animal, and 'kyer' which means catch. This has been the festival of the Effutu of Winneba with a history of initially, being the sacrifice of a human being to the god, Penkye Otu, before it was changed to the capture and sacrifice of a live leopard and then presently, the hunt, capture, and sacrifice of a live deer to the god. The hunt and capture of the deer is a competition between the two rival Asafo companies in the Effutu traditional area - the Tuafo No. 1 Company and the Dentsefo No. 2 Company. These two companies feature with their activities throughout the various contexts assigned to the festival.

Festivals are nearly always great occasions of music making as well as the occasions for public re-enactment of the beliefs and values on which the solidarity of the state depends (Agordoh, 2005). Thus, the celebration of the Aboakyer festival is characterized with the singing or performance of music for different activities during the celebration. Although there have been numerous writings on the Aboakyer festival celebration by many scholars as already stated, much attention has not been paid to the elements in the music that accompanies the celebration of the festival. By elements here, this paper refers to the instrumentation of the music, form, melodic structure, harmonic structure, and the song text used. The paper therefore seeks to bring to the fore the elements mentioned above by discussing the instruments that are used by the Asafo companies in accompanying the performance of the Asafo songs, the main form (s) that the Asafo songs take, the melodic as well as the harmonic structures of the songs, and what the Asafo companies sing about in terms of song text. Aboakyer festival has attracted so many scholars globally. This study, therefore, adds to the existing literature on the festival and reveals critical constituents of asafo musical genre for music creation in creative ethnomusicology and music education.

\section{Review of Related Literature}

Fynn and Addo-Fening (1991), in writing on the essence or importance of festival celebration, mentioned one of them as providing opportunities for the collective renewal of the arts as a form of community experience or as an expression of group consciousness. For this reason, the programmes of festivals were arranged in such a way as to culminate in a major public event in which artistic expression was given full scope which might take the form of drumming and dancing sessions which gave the scope for dramatic expressions, or durbars at which music of the court could be enjoyed. This assertion means that festival celebration is an opportune time for indigenous, migrant 
residents, and foreigners or tourists to witness the rich arts and values of the celebrating community. Music which could otherwise only be heard in the kings' courts or palaces is also then performed publicly for all.

In another development, Wyllie (1994) wrote on the celebration of the Aboakyer festival as visitor attraction and therefore gave a description of the impact of short-term tourism. He dwelt more on the tourist attraction provided by the Aboakyer festival. Takyi (2015) on the other hand, did a comparative study of the atonement concept in the Aboakyer festival of the Effutu tribe in Ghana and the Yom Kippur festival of the Old Testament and the implication for Adventist mission among the Effutu. His work was however virtually silent on the musical activities that go with the performance of some of the rituals during the celebration and other activities in the entire celebration. Similarly, in a study by Impraim-Swanzy (2015) on recent discoveries in the Aboakyer Festival of the Effutu, a history of the Effutus was given and a detailed narrative of events during the celebration of the festival was also done but did not provide anything on the music accompanying the performance of rituals, music for the procession to the forest for the deer hunt and other subsequent processions through the principal streets of Winneba. The study therefore fills this gap as a way of expanding scholarly writings in the area of musical performance in a cultural context.

\section{Methodology}

\subsection{Setting}

Located about 66 kilometres West of Ghana's capital, on the Accra-Takoradi road, Winneba is the capital and the only urban settlement in the Effutu Municipal Assembly. The indigenous people of Winneba are referred to as Effutufo and from Impraim-Swanzy (2015) and Ephrim-Donkor (2005), they were part of a large number of Guan tribesmen and led by their warrior kings - Kwamena Gyarteh, Ayirebi Gyan, and Gyarteh Siisi, they emigrated from Timbuktu, where the ancient empires of Northern Africa were crumbling as a result of frequent wars and famine. This began before the 12th century and Winneba was settled before the 13th century. Notable camps settled on their journey included Techiman (a popular market town in the Brong Ahafo region of Ghana today), Effutu village near present day Jukwaa and Amanfro which became Oguaa (Cape Coast) all in the Central region of Ghana. The name Simpa, which happens to be the original name of the town came from the naming of the "new found land" after Osimpam Bondze Abe, a son of Kwamena Gyarteh, who led a search party to look for the land and moved the people to the present settlement. Unfortunately, Osimpam died not long afterwards and was the first to be buried on the land and the place was subsequently named after him. According to an informant, Simpa was a vibrant commercial centre during the 17th, 18th, and 19th centuries. The evidence of this is clear since Simpa's sea shore is a bay which means "an outlet of the sea or other body of water usually smaller than a gulf" and this bay is also a natural harbour meaning "a part of a body of water protected and deep enough to furnish anchorage; especially, one with port facilities” (Encyclopedia Britannica, 2009).

This natural endowment brought a lot of trade and commercial activities onto the "new found land". Consequently, in addition to the European navigators' forts built for their administrative purposes, companies like UTC, SCOA, FAO, PZ, and UAC also built warehouses at Simpa and ruins of these edifices can still be seen in the town today. To be able to trade effectively, commerce was harmonized with Christian religion (Mazuri, 1986) and for efficiency and maximization of profits in their trade, education for their African employees, as well as their African wives and children became crucial (Gadagbui, 1998). As a result, Simpa flourished as it was dragged along into a world culture that was primarily Eurocentric. The new Western settlers named Simpa "Windy Bay". The name Windy Bay is what was corrupted as Winneba, Winneba, Winneba which has remained the official name of the town even though the indigenous people still call it Simpa.

Immigrant groups eventually become incorporated in a mainstream society and adopt social norms, values, culture, and sense of people hood (Kurashige, 2002). In this regard, the norms and culture adopted are the commemoration of events and the celebration of festivals. Festival, according to the World Book Encyclopedia (2001), is a special time of celebration. Most of them take place once a year and may last for one or more days. Many festivals honour great leaders, saints or gods or spirits. Others celebrate a harvest, the beginning of a season of a year, or the anniversary of a historical event.

\subsection{Process}

The study focused on the music performed during the celebration of the Simpa Aboakyer Festival. Thus, the nature of information involved informed the choice of a field work design. The study was rooted in the Ethnographic research design. As indicated by Bhattacharya (2017), ethnographic research is a qualitative method where researchers observe and or interact with a study's participants in their real-life environment. The design enabled the researcher to conduct interviews, participated and observed the activities during the festival as a way of gathering as much information as possible. Using purposive sampling, the study made use of a total sample size 
of 14 which comprised 2 song leaders and 5 singers from each of the two Asafo companies - Tuafo No. 1 and Dentsefo No. 2. The musical activities from the beginning of the festival through to the end were observed and recorded. In some of the musical activities, I participated and learnt some of the song texts. Various contexts in the festival were noted and recorded. How the asafo groups selected their songs in the various contexts was noted. Song themes and how they were applied in their activities were recorded in a notebook. The musical instruments used for the accompaniment were observed and noted while the songs of the asafo groups were also recorded with a mobile phone and uploaded on a laptop computer. The collected songs were transcribed using music notation software, Finale 2012 and analysed for its mode, tonality, harmony and melody.

\section{Discussion of Findings}

The findings from the study was done on the lines of (i) a general description of activities during the celebration of the festival which involve the performance of music and (ii) a presentation of the characteristic features of the Asafo music performed during the festival celebration.

\subsection{Musical Activities in Aboakyer Festival}

From the interview granted me by the song leaders and singers sampled, activities leading to the grand durbar, which is on the first Saturday of May, include prayers to the deity on the Saturday preceding it for protection of the Asafo companies. The deity is then guarded up to Wednesday on which one of the gods, named "Eku" and described as the 'god of peace' is consulted to give directions as to what the Asafo men should do when they go into the forest for the hunt and also for their protection from wild animals and any ill-fate that may befall them in the forest. A day to the climax of the festival (Friday) is when each of the two Asafo companies goes for its deity to parade around town with all members of the company and as many visitors as possible who may like to go on the procession with them amidst singing and dancing.

The musical performance of the Asafo can be viewed as an organization that operates within a specific and distinct organizational structure of the festival because music plays an inseparable role in all the activities discussed so far. For the offering of prayers to the gods, the libation poured is done alongside singing which mainly serves as appellations to the gods. Like Norton (2000) indicated, songs employed in rituals invite the spirits although the song text changes depending on the spirit incarnated. Similarly, the parading of the deities on Friday is followed with singing and dancing whilst as a way of motivating or encouraging themselves as they go for the catch the next day, Saturday, the Asafo companies chant mainly their war songs. On their return, songs of victory and excitement for a catch are heard and they continue with the parading of the catch (the deer) on the durbar grounds before and after presenting it to the chief. The afternoon of the durbar day is when all the chiefs, queen mothers, and people of the traditional area parade or process through the principal streets amidst drumming, singing, and dancing. Prior to this afternoon activity, that is the procession by the general public, it is the traditional Asafo songs that are performed to accompany the activities and the performances are dominated by men. Datta, et al. (1971) talked about the patrilinieal system of asafo among the Fante communities:

A feature of the asafo system is the operation within it of the principle of patrilineal succession as opposed to the matrilineal succession normally operating in Fante kinship matters. The external manifestation of patrilineal succession in the asafo system lies in an individual's affiliation to his father's company, as also in his succession to his father's office in certain cases. Additionally, a man gets his first gun from his father and inherits the latter's protective charm against dangers in war. (p. 281)

This shows that asafo is a prerogative of men; however, women are often seen during the procession on the Saturday afternoon performing and accompanying their music with gourds. Mention needs to be made of the fact that, perhaps, due to modernity and for the sake of the youth who may not be well-versed in the singing of the Asafo songs or may not show much interest in the Asafo songs performance, other types of music are included in the form of popular music played from loud speakers on trucks. With these, every participant in the celebration, especially, non-indigenes or foreigners get something to cheer about and also sing along at the festival. The consideration of the participation of the youth with the provision of their contemporary music makes some aspect of the festival a "youthful" and "modern" event" (Tochka, 2012).

\subsection{Features of the Aboakyer Asafo music}

The features of the musical performances among the two asafo companies were examined in terms of musical instruments, form of the songs, melodic structure, harmonic structure and song texts.

\subsubsection{Musical instruments Used}

Musical instruments are devices for producing a musical sound. The principal types of such instruments, classified by the method of producing sound, are membranophones, aerophones, chordophones and idiophones (Von Hornbostel et al., 1961). It was discovered that the two rival companies, used similar and different instruments by 
which one could use to identify which company was performing at each point in time. In performing their music, both companies made use of three drums each, which were all membranophones. These were Akomfor, Apagyafo, and Kyeremfo for the Tuafo No. 1 Company whereas the Dentsefo No. 2 used Nkyirimbafo, Petufo, and Asomfo. These drums come in different sizes and pitches. The difference, in terms of instrumentation, between the two companies is rather identified in the other instruments used apart from the drums. Whilst the Tuafo No 1 Company uses the bugle, cog-wheel rattle, and the three-in-one gong, the Dentsefo No. 2 Company makes use of a bell and two-in-one gong.

\subsubsection{Form of the music}

In music, form refers to the structure of a musical composition or performance (Lidov, 2005). Musical form unfolds over time through expansion and development. Technically, the form of a musical work can be described minimally as a hierarchical arrangement of discrete, perceptually significant time spans, what has been termed the grouping structure of the work (Caplin, 1998). The Asafo music used in the celebration of the Aboakyer festival is mainly performed in the 'call and response' pattern. Almost every song sung is raised or called by either the leader of the ensemble or any member of the group who may get an inspiration from the deity to raise any particular song. It behooves on the other singers to respond to the song no matter who raises it although there are some occasions when the performers insist the songs come from the leaders alone. This is done to avoid confusion as to who is calling and which song to respond to. Also, some form of 'theme and variation' is heard from the leader either in the course of the response to the call or when doing subsequent calls after the first. A theme and variation is a form of music that begins with a main melody (the theme) that is then altered or changed in some way throughout the piece (Walton, 2005) Here, the leader tries to vary his style of the theme after the first and also after each variation or call and this makes the performance more interesting and less monotonous. In the words of Hyslop (1955), "the most suitable African songs are those commonly sung by a leader and chorus, of which there is an almost infinite number and variety" (p.53).

\subsubsection{Melodic Structure}

Schmidt-Jones (2012) describes a melodic phrase as a group of notes that make sense together and express a definite melodic idea, but it takes more than one phrase to make a complete melody. Recognizing the structure of a melody is an essential part of musical listening. Although a model of melodic structure is needed for analytical research as well as for practical applications, no generally accepted theory of melodic structures has yet been developed. Neither is it generally clear how melodic structures can be found, nor is it agreed on exactly what melodic structures are. Yet there are two aspects that are essential for most theories of melodic structure: segmentation and similarity (Weyde, 2002). Listening to the melodies of the Asafo music, apart from a few of them being lyrical, most of the melodies are more of a recital or carry a speech-rhythm. This is to say that instead of the melodies flowing smoothly, the Asafo music may sometimes be likened to a recitative. This is especially seen or heard in the performance of songs for the gods. See Example 3. However, when it comes to the performance of songs for a dance like the Akosuadontoba by the Tuafo, and Dwombir by the Dentsefo during the procession on the festival day, songs used or performed are more lyrical, steady in rhythm and flow more easily. See Example 1 which is an Akosuadontoba tune.

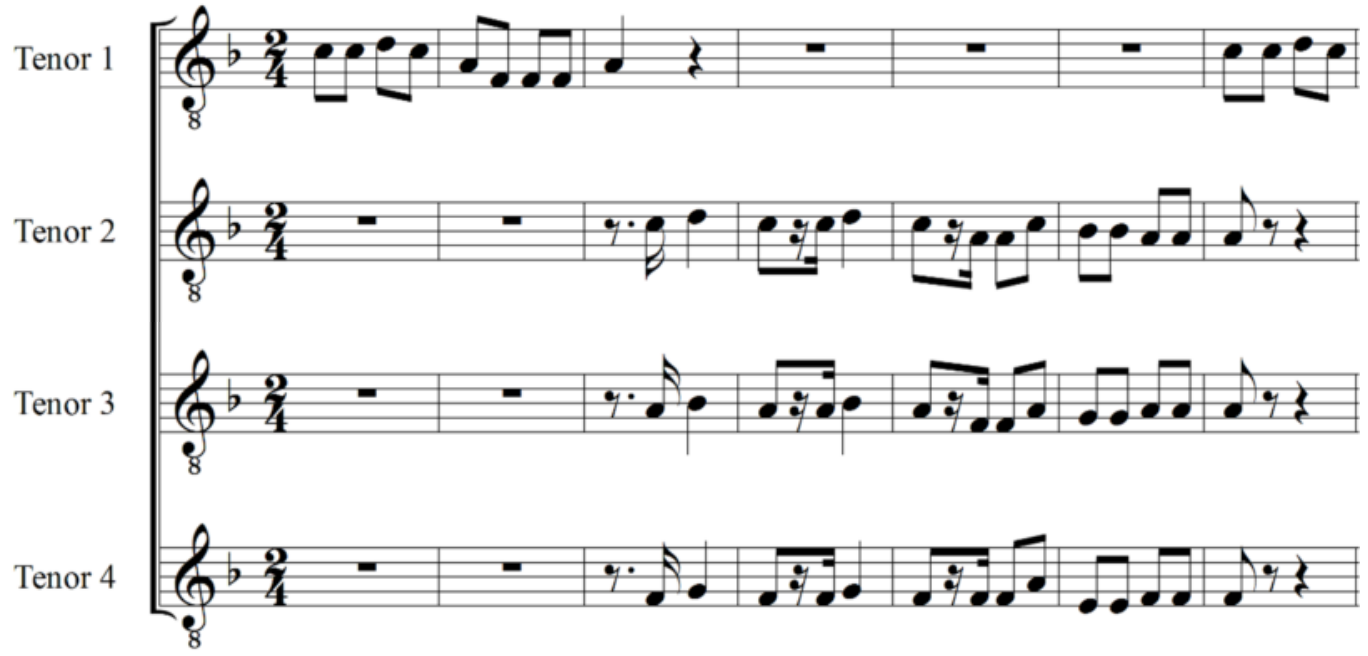

Example 1: Akosuadontoba tune 


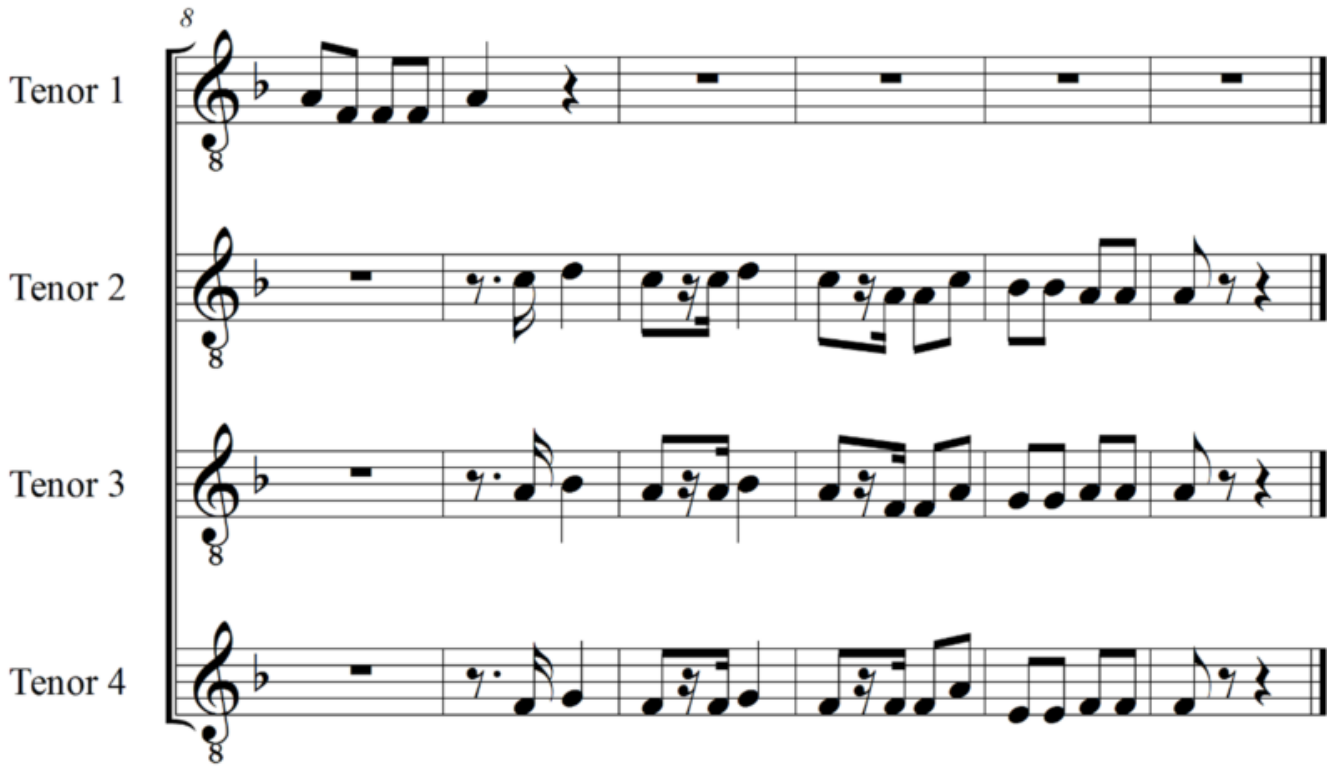

Example 2: Continuation of Akosuadontoba dance tune

Again, concerning tonality, the Asafo songs are mostly modal. It is most of the time, quite difficult to ascertain the particular mode in which a song or melody is being performed. The melodies rarely end on the tonic but rather on the median which makes it Phrygian. The genre also makes much use of pitch-bends especially at the end of the responses.

\subsubsection{Harmonic Structure}

Goetchius (2013) also explains harmony as a consistent, orderly, or pleasing arrangement of parts; congruity of musical sound. Meaning, any simultaneous combination of tones, especially when blended into chords to please the ear is harmony. Indeed, one is rarely likely to hear a four-part harmony from Ghanaian traditional music performers. Some of the songs performed during the celebration by the Asafo companies are done in unison and others in two or three-part. In an area where the performers of the Asafo music are mainly fishermen who do not have any formal training in music, responding to or singing most of their songs in harmony is done in simple thirds and sixths. This is typical with most Ghanaian traditional ensembles. Example 3 shows the form and harmonic structure employed in the performance of Asafo music.

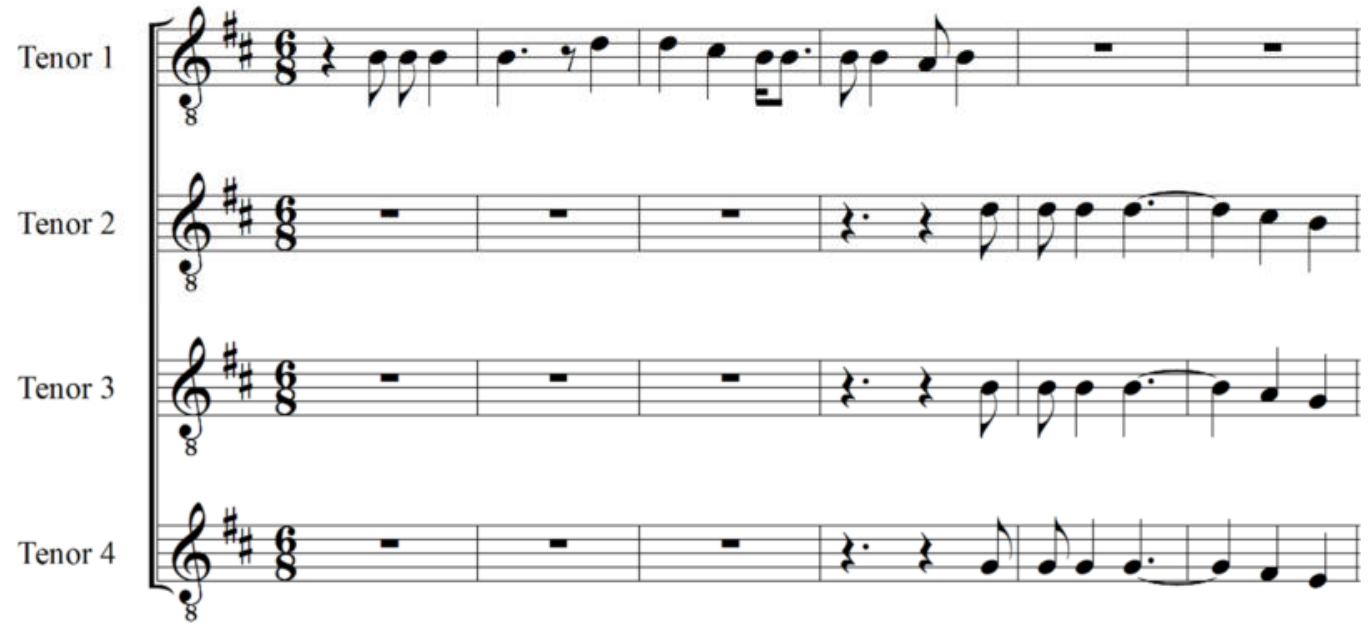




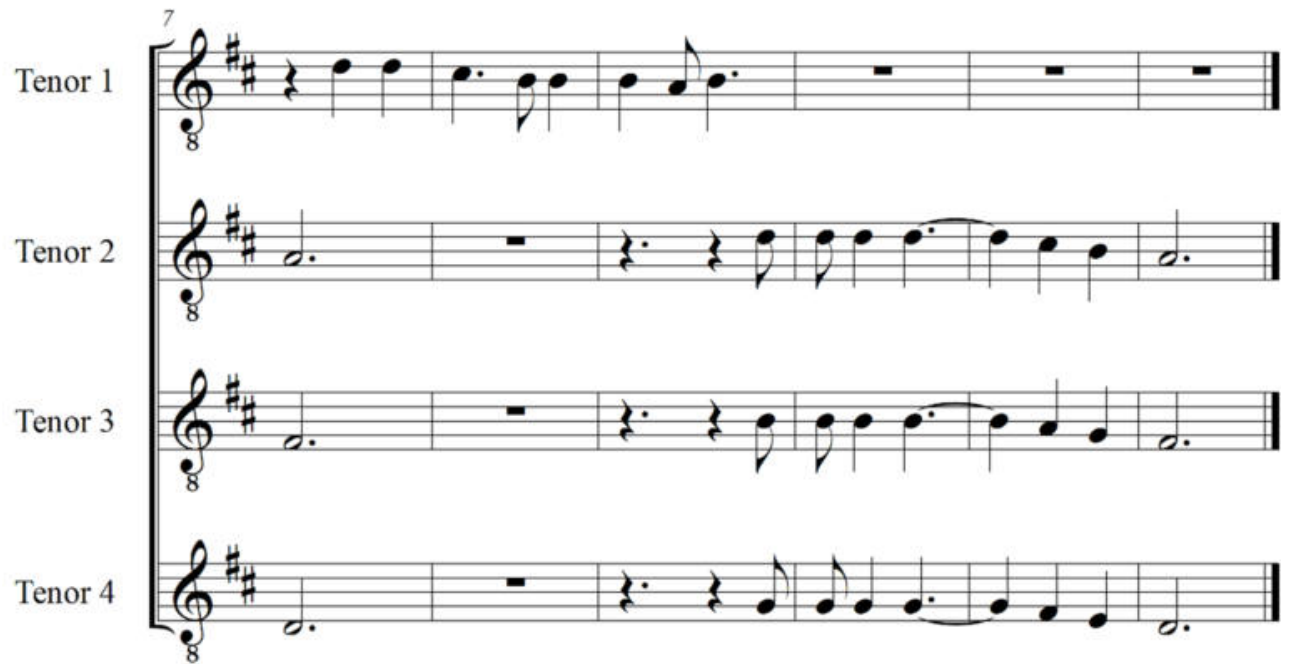

Example 3: Excerpt showing form and harmonic structure

\subsubsection{Song Text}

In the celebration of festivals, music and song-texts are deployed to articulate social and political agendas and power relations as shaped within the context of democratic politics (Omojola, 2011). Thus, the Asafo companies, as gathered from the interviews and observations, do not only sing to entertain celebrants of the festival during the period but it was realized that virtually every song raised or sung by the companies was utility-purpose borne. The selection of songs sung during the festival celebration depends on the day and particular activity in progress. With the choice of an appropriate song to sing before or after another, it sometimes comes as an inspiration from the gods to any member of the group who will then raise it for the others to join or as a call for the others to respond. Example 4 is an excerpt of one of the songs sung for the 'god of peace', Eku,

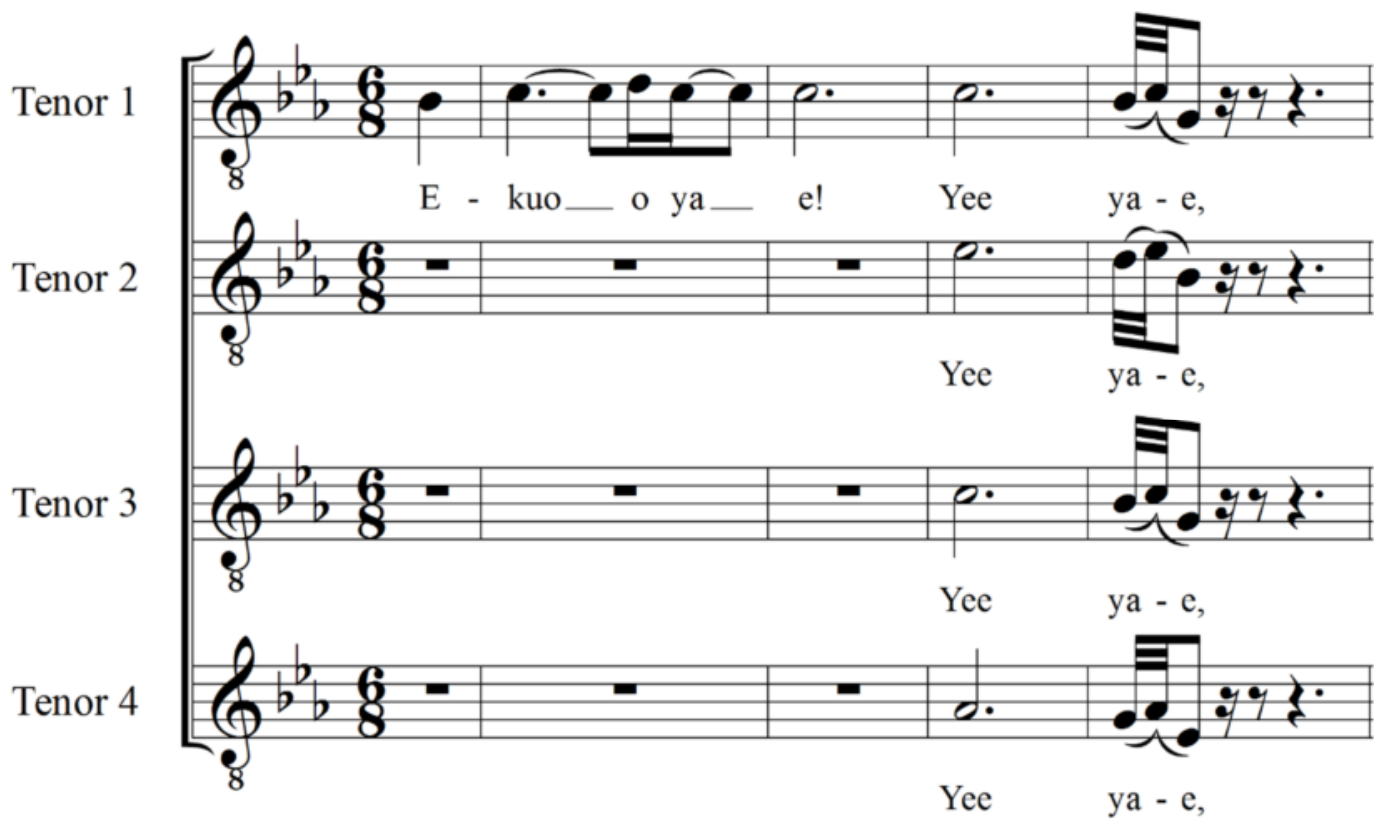




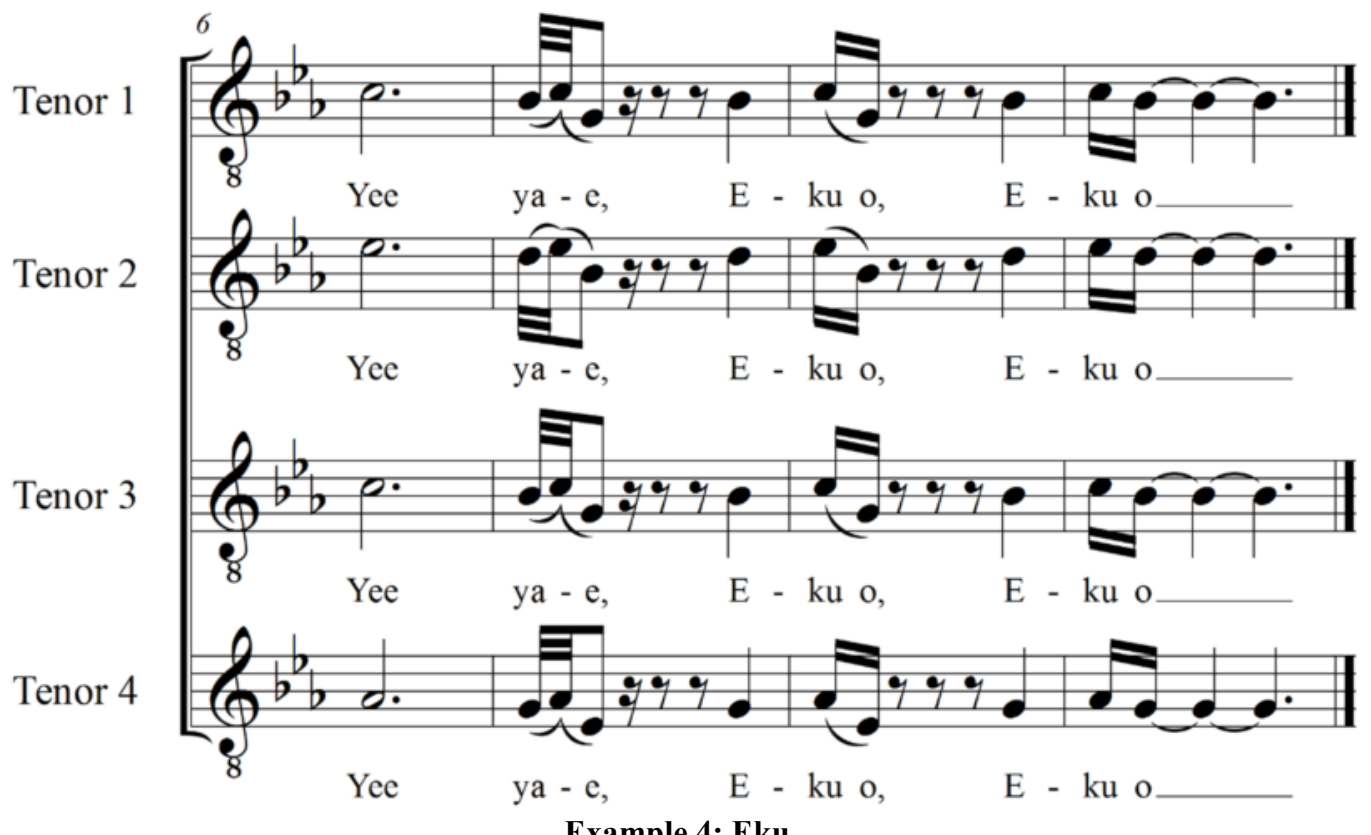

On song text, the two companies have lyrics in their songs which always try to depict something peculiar about the company. Due to the rivalry that exists between them, each company does its best to sing, using words that tend to speak for the company or against its rival company. In line with this, one of the themes on which singers base their songs is that of insinuation. During the festival period, rivalry between the two companies heightens and one way of speaking against either company is through singing and with the text or lyrics in the song. Each of the two companies tend to, as much as possible, sing songs or choose words that insinuate against the other. An example is a song by the Tuafo No. 1 Asafo Company which seeks to remind the Dentsefo No. 2 Asafo Company that they were once chased away by the Tuafo, making them leave their drums behind for them to take and use an act they consider as defeat. The song with its text is shown in Example 5.

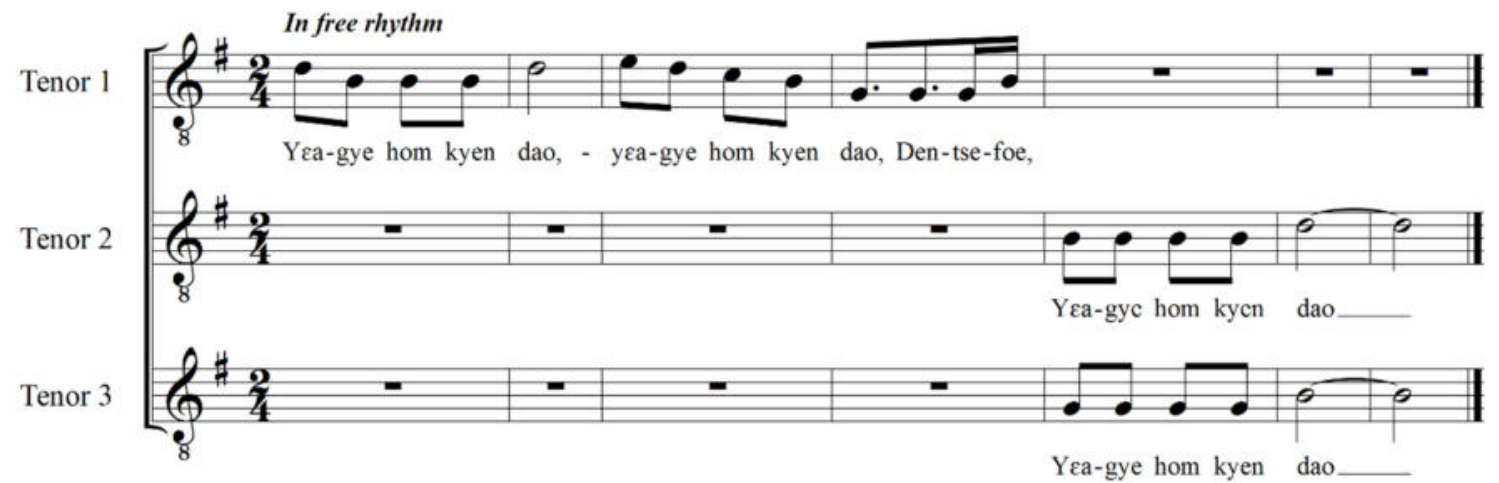

Example 5: Yeagye hom kyen da

Apart from some of the song text used in casting insinuations, some of the text in the Asafo music also depict or talk of how brave each company is. The next example, 6 , is an excerpt of one such song. The text seeks to dare anyone who calls himself a man to come forward. 


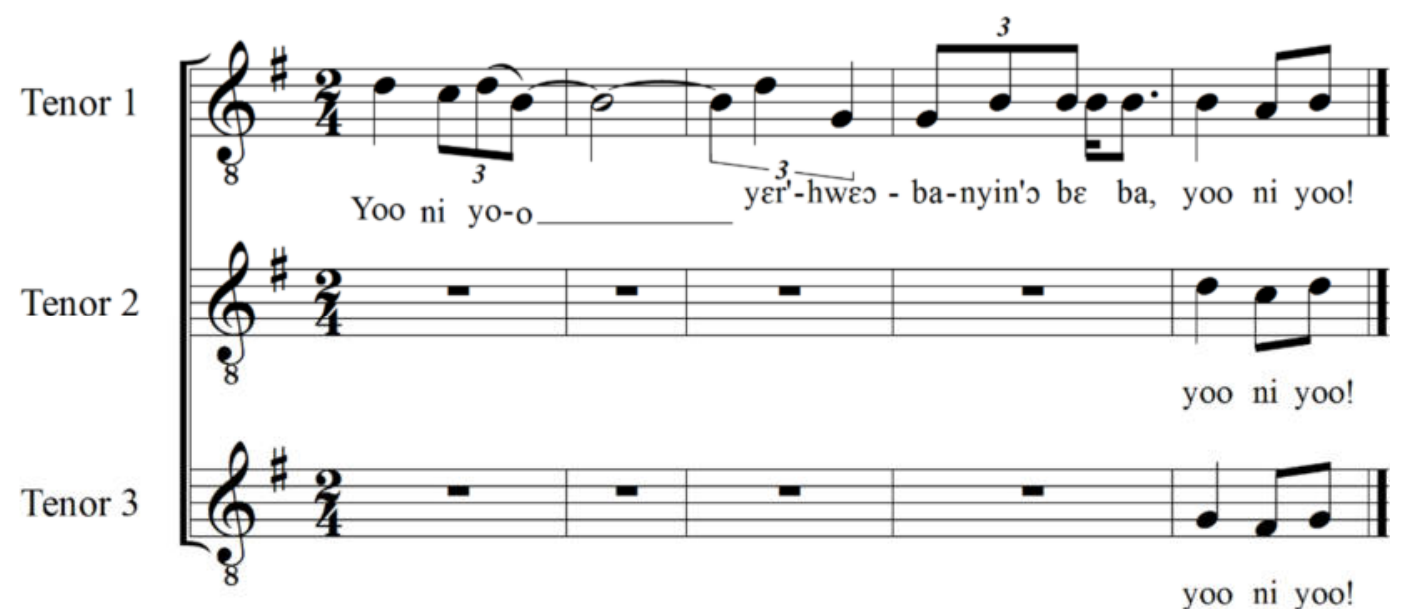

Example 6: Banyin a sbeba

Finally, being an occasion to also remember and appreciate their founding ancestors, some of the songs and song texts talk in praise of the founders of Simpa and forefathers of the two Asafo companies. The text in Example 7, for instance, salutes the forefathers for their efforts in getting a place for them to settle.

Tenor

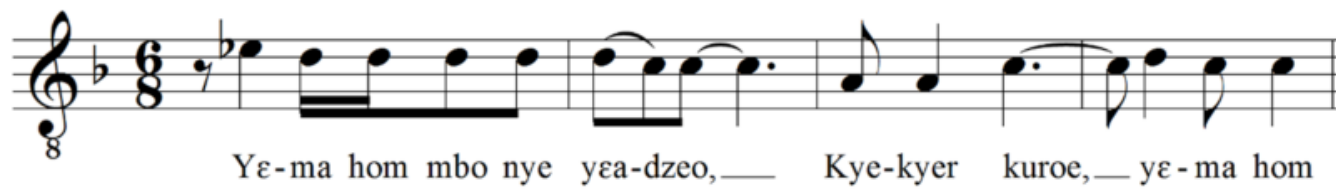

Tenor

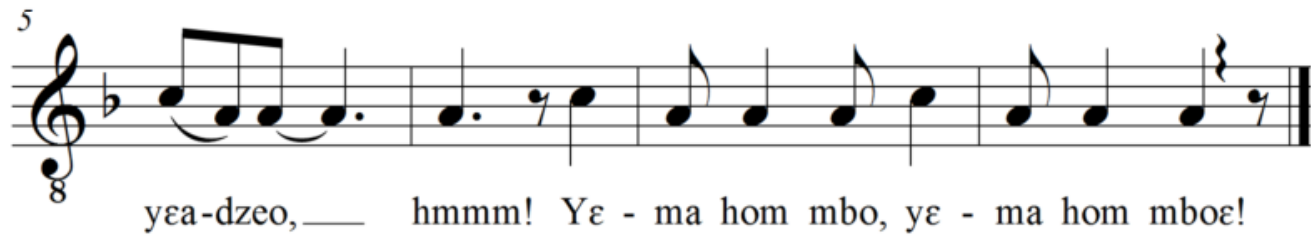

Example 7: Mbo nye yeadze

\section{Conclusions}

Performance of music is virtually inseparable from the activities performed during the celebration especially the performance of the Asafo music; and the characteristic features discussed apply to the music performed by the two rival companies - Tuafo No. 1 and Dentsefo No. 2 - with the main difference coming from the instrumentation and song text by each company. Also, the Asafo songs performed in public can be joined by anyone who wishes to sing along and this could be with either of the two companies of the follower's choice. Then, the performance of the Asafo songs could be said to come from two sources being either from a song leader or any member of the company who may be moved by the deity to raise a song. Furthermore, the Asafo music performed are mainly in call and response form, the melodies being modal and the use of simple 3rds and 6th intervals for harmony. Finally, the song text used in the performance of the Asafo music speak as appellations to the gods, cast insinuations against rival companies, talk of the bravery of each company, provide history of events, and also sing in praise of the forebears of Simpa.

\section{References}

Adjepong, B., \& Obeng, P. (2018). The role of performing arts in Ghanaian society and its implication for formal education in primary schools. European Journal of Education Studies, 5(6), 221-226.

Agordoh, A. A. (2005). African music: Traditional and contemporary. New York: Nova Publishers. 
Bhattacharya, K. (2017). Fundamentals of qualitative research: A practical guide. Taylor \& Francis.

Brown, K. E. (2005). Social conflicts in contemporary Effutu festivals (Doctoral dissertation, Bowling Green State University).

Caplin, W. E. (1998). Classical form: A theory of formal functions for the instrumental music of Haydn, Mozart, and Beethoven. Oxford University Press.

Datta, A. K., \& Porter, R. (1971). The Asafo system in historical perspective. Journal of African History, 279-297.

Encyclopedia Brittanica (2009). Social Science Research. In Ultimate Reference Suite. Chicago: Encyclopedia Britanica.

Ephirim-Donkor, A. (2005). Celebrating Aboakyer 2005 with NeenyiGhartey VII. Unpublished.

Fynn, J. K., \& Addo-Fening, R. (1991). History for Senior Secondary Schools. Ministry of Education, Accra: Evans Brothers Ltd, London.

Gadagbui, G. Y. (1998). Education in Ghana and special needs children. Accra: City Publishers.

Ghunney, E. A. (2015). Gyamkaba: An original composition derived from Asafo songs of Aboakyer festival of Winneba. Unpublished MPhil. Thesis. University of Education, Winneba.

Goetchius, G. (2013). Noise, Vibration and" Harshness??". Sound \& Vibration, 47(4), 5-7.

Hyslop, G. H. (1955). Choice of music for festivals in Africa. African Music, 1(2), 53-55.

Impraim-Swanzy, E. (2015). Recent Discoveries in the Aboakyer Festival of the Effutus-Ghana. Research on Humanities and Social Sciences, 5(2), 172-182.

Kurashige, L. (2002). Japanese American Celebration and Conflict: A History of Ethnic Identity and Festival. California: Univ of California Press.

Lidov, D. (2005). Is language a music?: Writings on musical form and signification. Indiana University Press.

Mazrui, A. A. (1986). Cultural synthesis in Africa: Postcolonial Africa struggles for cultural authenticity. Retrieved from:http://www.worldandi.com/public/1986/february/cl3.cfm

Norton, B. (2000). Vietnamese mediumship rituals: The musical construction of the spirits. The world of music, 75-97.

Omojola, B. (2011, April). Oșogbo: Power, Song and Performance in a Yoruba Festival. In Ethnomusicology Forum(Vol. 20, No. 1, pp. 79-106). Taylor \& Francis Group.

Schmidt-Jones, C. (2012). The basic elements of music. Connexions.

Takyi, E. H. (2015). A Comparative Study of the Concept of Atonement in the Aboakyer Festival of the Effutu Tribe in Ghana and the Yom Kippur Festival of the Old Testament: Implications for Adventist Mission Among the Effutu. Dissertations. Retrieved from https://digitalcommons.andrews.edu/dissertations/1575

Tochka, N. (2012). Creating light music at the festival of song: Politics, personhood, and cultural production in Tirana, Albania (1944-present) (Doctoral dissertation, The Graduate School, Stony Brook University: Stony Brook, NY.).

Von Hornbostel, E. M., \& Sachs, C. (1961). Classification of musical instruments: Translated from the original german by anthony baines and klaus p. wachsmann. The Galpin Society Journal, 3-29.

Walton, C. W. (2005). Basic Forms in Music. Alfred Music.

World Book Encyclopedia (2001). Festival. Chicago: World Book Inc.

Weyde, T. (2002). Integrating segmentation and similarity in melodic analysis. in Proceedings of the International Conference on Music Perception and Cognition 2002. - ICMPC7, 17 - 21 Jul 2002, Sydney, Australia.

Wyllie, R. W. (1994). Gods, locals, and strangers: The Effutu Aboakyer as visitor attraction. Current Anthropology, 35(1), 78-81. 